\title{
Assessment of Food Safety Knowledge, Attitude, Self-Reported Practices, and Microbiological Hand Hygiene of Food Handlers
}

\author{
Hui Key Lee ${ }^{1}$, Hishamuddin Abdul Halim ${ }^{2}$, Kwai Lin Thong ${ }^{1}$ and Lay Ching Chai ${ }^{1, *}$ \\ 1 Institute of Biological Sciences, Faculty of Science, University of Malaya, Kuala Lumpur 50603, Malaysia; \\ huikey90@gmail.com (H.K.L); thongk1@um.edu.my (K.L.T) \\ 2 Occupational Safety \& Health Unit, Registrar's Department, University of Malaya, Kuala Lumpur 50603, \\ Malaysia; hishamuddin@um.edu.my \\ * Correspondence: lcchai@um.edu.my; Tel.: +603-7967-5832
}

Academic Editor: Paul B. Tchounwou

Received: 3 September 2016; Accepted: 26 December 2016; Published: 10 January 2017

\begin{abstract}
Institutional foodborne illness outbreaks continue to hit the headlines in the country, indicating the failure of food handlers to adhere to safe practices during food preparation. Thus, this study aimed to compare the knowledge, attitude, and self-reported practices (KAP) of food safety assessment and microbiological assessment of food handlers' hands as an indicator of hygiene practices in food premises. This study involved 85 food handlers working in a university located in Kuala Lumpur, Malaysia. The food safety KAP among food handlers $(n=67)$ was assessed using a questionnaire; while the hand swabs $(n=85)$ were tested for the total aerobic count, coliforms, and Escherichia coli, Staphylococcus aureus, Salmonella, Vibrio cholerae and Vibrio parahaemolyticus. The food handlers had moderate levels of food safety knowledge (61.7\%) with good attitude (51.9/60) and self-reported practices (53.2/60). It is noteworthy that the good self-reported practices were not reflected in the microbiological assessment of food handlers' hands, in which $65 \%$ of the food handlers examined had a total aerobic count $\geq 20 \mathrm{CFU} / \mathrm{cm}^{2}$ and Salmonella was detected on $48 \%$ of the food handlers' hands. In conclusion, the suggestion of this study was that the food handlers had adequate food safety knowledge, but perceived knowledge failed to be translated into practices at work.
\end{abstract}

Keywords: food safety; food handler; KAP; microbiological assessment; hand hygiene

\section{Introduction}

The World Health Organization (WHO) reports that there approximately 2 million fatal cases of food poisoning occur every year globally [1], especially in developing countries. This scenario could be due to the poor state of food safety and general hygiene in those countries. In 2014, Malaysia recorded 49.79 cases of food poisoning per 100,000 population [2]. More than $50 \%$ of the total food poisoning cases were attributed to improper food handling by food handlers [3]. The outbreaks in academic institutions contributed $43 \%$ of the total foodborne poisoning incidents in Malaysia [4]. The Ministry of Health Malaysia [5] has identified ineffective food handling training, the use of untreated water for non-drinking purposes, and poor sanitation and hygiene as the primary risk factors of food poisoning in the country.

Food handlers play a paramount role in ensuring food safety and prevention of food poisoning. Michaels and co-workers [6] reported that infected food handlers were able to transmit agents of gastrointestinal infectious diseases via poor personal hygiene practices. A previous study successfully isolated Salmonella from seafood [7] but Salmonella is not a common carrier. This was thought to be a result of cross-contamination by infected food handlers [7]. Moreover, many reports have demonstrated 
similarities between the pathogens isolated from patients and food handlers, clearly indicating that food handlers were the vehicles of transmission for the foodborne pathogens [8,9]. Angelillo et al. [10] suggested that food handlers who had good knowledge of proper food handling practices could help to control food poisoning cases as they were in direct contact with food, particularly ready-to-eat foods.

Poor personal hygiene, primarily ineffective hand washing, has been recognised as a significant risk factor of food contamination that leads to food poisoning [11,12]. Hand hygiene is the most basic yet critical criterion for ensuring safe food handling by food handlers. In fact, hand washing has long been known to be a fundamental precautionary measures in health care settings [13], as well as in the kitchen, for preventing the spread of infectious disease through human to human or human to food contact [14-17]. Therefore, it is thought that hand hygiene could serve as an indicator of food handlers adherence to safe food practices during food preparation.

In Malaysia, it is mandatory under the Food Act 1983 for all food handlers to attend and complete the safe food handling course established by the Malaysian government, and they need to be vaccinated against typhoid since this disease is endemic in Malaysia. Many local studies have reported that the food handlers are mostly foreign contract workers who have adequate knowledge, positive attitudes, and good self-reported practices [18-20]. Nevertheless, the food poisoning rates in this country have still been increasing since 2000 [21]. The discrepancy observed between the previous research findings and epidemiological statistics have motivated us to compare the real practice of hygiene to the knowledge, attitude, and self-reported practices related to food hygiene and safety among food handlers.

Information on the food safety and hygiene practices of food handlers is scant. Thus, this study focused on assessing the food safety knowledge, attitude, and self-reported practices among food handlers via a questionnaire, in addition to hand hygiene assessment via microbiological assays. By combining both approaches, the findings provided us with a better understanding of the extent of translation of knowledge into real hygiene and safety practices as reflected in the hand hygiene of food handlers. The data generated provides an important basis for planning and determination of further approaches to be taken to improve food safety in the country.

\section{Materials and Methods}

The ethical approval was obtained from the University of Malaya Medical Ethics Committee for this study (RP003-13BIO) while informed consents were obtained from the participants.

\subsection{Sampling Plan}

This study includes all the food handlers working in canteens located in the university campus. There are 18 canteens in the university with 250-300 food handlers (inclusive of permanent and contract workers). However, we only managed to get consent from 111 food handlers to take part in the study. Of these, 41 food handlers $(36.9 \%)$ participated in both the questionnaire and microbiological hand hygiene assessment; while 26 (23.4\%) and 44 (39.6\%) food handlers participated only in the questionnaire and microbiological hand hygiene assessment, respectively. The reason for the unbalanced sampling was because the questionnaire and hand hygiene assessment were conducted at different times and some contract workers had already left their jobs at the time that the microbiological hand hygiene assessment was conducted. Therefore, to increase the number of participants in the hand hygiene assessment, new workers who gave consent were included.

\subsection{Questionnaire Collection}

The questionnaire was in dual languages (English and Malay language) and consisted of 97 items on demographic information (11 items), food safety knowledge (60 items), attitude (14 items), and self-reported practices (12 items). Food safety knowledge was assessed based on six constructs: (1) personal hygiene; (2) cross-contamination prevention and sanitation; (3) food handling; (4) health problems that would affect food safety; (5) symptoms of foodborne diseases and (6) foodborne pathogens. Items in construct 1-4 were based on basic content taught in the safe food handling course 
Malaysia. The respondents were required to choose either "true" or "false" for each item on food safety knowledge and the score was given for each correct answer. The overall performance on food safety knowledge was converted to a percentage by dividing the total score over the total number of items of food safety knowledge. While the food safety attitude and self-reported practices were assessed by four-level and five-level Likert scale questions, respectively. For items under the attitude section, the lowest point (1 point) was given to "disagree" to the highest (4 points) for "agree"; while the self-reported practices were scored from the lowest ( 1 point) for "never" to the highest (5 points) for "always".

We collected questionnaires from 67 food handlers of contract and/or permanent status from twelve food premises within the campus from December 2013 to August 2014. The participation of food handlers in this study was conducted on a voluntary basis. A self-administered questionnaire adapted from previous studies $[22,23]$ was given to the literate food handlers; whereas the illiterate food handlers were assisted by a trained moderator in answering the questionnaire.

\subsection{Hand Hygiene Assessment}

\subsubsection{Sample Collection}

A second visit to the food premises was done to collect hand swabs from the participants who had answered the questionnaire. However, during the visit, hand swabs were not performed for 26 participants who had already left the job. In the meantime, hand swabs were also collected from new workers $(n=44)$ who were willing to participate in this study. Therefore, a total of 85 hand swab samples were collected.

Each sterile swab was dipped into a falcon tube containing $10 \mathrm{~mL}$ of maximum recovery diluent (MRD; Merck, Darmstadt, Germany) to moisten the swab tip and then swabbed over the palm and fingertips of the food handler's hand. A swab was collected from each food handler. The hand swabs were collected from 11.00 a.m. to 3.00 p.m. while the food handlers were serving lunch, then transported in MRD as a transport medium to the laboratory within $2 \mathrm{~h}$ for immediate laboratory analysis.

\subsubsection{Sample Enrichment and Enumeration by Plate Count Method}

The hand swab was vortexed for 10 seconds to release bacteria from the cotton swab. Ten-fold dilution was made for further enumeration. Microbial loads of aerobic bacteria, coliforms, Escherichia coli (E. coli) and Staphylococcus aureus (S. aureus) were analysed using Petrifilm ${ }^{\mathrm{TM}}$ Aerobic plate count, E. coli/coliforms plate count, Staph Express plate count, respectively. Petrifilm ${ }^{\mathrm{TM}}$ plates were incubated as stated in the manufacturer's instructions. For each type of microbial enumeration, a duplicate test was carried out to validate and ensure reproducibility. The average surface area of hands used in calculation of bacteria count on food handler's hand $\left(\mathrm{cfu} / \mathrm{cm}^{2}\right)$ was obtained from study by Lee et al. [24], while the thresholds of the aerobic bacteria, coliforms, E. coli, and S. aureus counts were adopted from study by Tan et al. [25] and Sneed et al. [26].

2.3.3. Detection and Enumeration of Salmonella spp., V. cholerae and V. parahaemolyticus Enumeration by Polymerase Chain Reaction (PCR)

The Most Probable Number (MPN) three-tube method was applied to quantify Salmonella spp., $V$. cholerae and V. parahaemolyticus of the hands of food handlers. Buffered peptone water (Merck) was used as the pre-enrichment broth Salmonella spp. whereas the alkaline peptone water (Merck) was used as an enrichment medium for $V$. cholerae and parahaemolyticus. The MRD containing bacteria from the hands of food handlers was diluted with enrichment medium and incubated overnight at $35 \pm 2{ }^{\circ} \mathrm{C}$ in $1.5 \mathrm{~mL}$ microcentrifuge tubes. The enriched samples were subjected to DNA extraction and then Polymerase Chain Reaction (PCR) assay was used for Salmonella spp., Vibrio cholerae and V. parahaemolyticus detection.

DNA templates were prepared using the boiling method. A pair of primers namely OMPCF/OMPCR designed by Alvarez et al. [27], were used for Salmonella spp. detection while 
primers named pntA $1 \mathrm{C} / 2 \mathrm{C}$ and pntA $1 \mathrm{P} / 2 \mathrm{P}$ were used [28] for $V$. cholerae and $V$. parahaemolyticus detection. PCR products were analysed by using $1.5 \%$ of LE agarose (Promega, Madison, WI, USA) at $100 \mathrm{~V}$ for $30 \mathrm{~min}$. All the oligonucleotides used were commercially synthesised (IDT, Coralville, IA, USA). The laboratory culture collections in this study, Salmonella enterica subsp. serovar Enteritidis (SE H16), Vibrio cholerae 86020, and Vibrio parahaemolyticus J 42 were used as the positive controls.

\subsection{Statistical Analysis}

Although there were 67 questionnaires and 85 hand swabs obtained, the total number of food handlers participating in both questionnaire, and microbial assessment was 41 . Both questionnaire and microbial assessments were done by volunteering. Thus, there was a discrepancy in the number of samples in each part of the study. The statistical analyses were carried out using an IBM SPSS Statistics Version 22 (IBM, New York, NY, USA). Independent samples $t$-test was applied in analysing the significant differences between self-reported practices of food handling and the microbiological hygiene assessment results. The two-sided $p$-value was set at 0.05 .

\section{Results}

Approximately $64.2 \%(n=43)$ of the food handlers who undertook the questionnaire were aged from 21 to 41 years old; while $61.2 \%(n=41)$ were of foreign nationality. More than half of the participants $(n=36,53.7 \%)$ had $\geq 2$ years' experience in the food service industry (Table 1$)$. Out of 67 food handlers involved in this study, a quarter $(n=17,25.4 \%)$ of the food handlers had not attended the safe food handling course, which is compulsory under the Malaysian Food Act 1983; and therefore, most of these untrained food handlers were not vaccinated for typhoid fever either (Table 1).

Table 1. Participant demographic characteristics.

\begin{tabular}{|c|c|c|c|}
\hline Variable & Item & Number & Percentage $(\%)$ \\
\hline \multirow[b]{2}{*}{ Gender } & Male & 27 & 40.3 \\
\hline & Female & 40 & 59.7 \\
\hline \multirow{3}{*}{ Age } & $<21$ years old & 5 & 7.5 \\
\hline & $21-41$ years old & 43 & 64.2 \\
\hline & $>41$ years old & 19 & 28.4 \\
\hline \multirow{2}{*}{ Nationality } & Malaysian & 26 & 38.8 \\
\hline & Foreigner & 41 & 61.2 \\
\hline \multirow{3}{*}{ Marital Status } & Single & 14 & 20.9 \\
\hline & Married & 49 & 73.1 \\
\hline & Divorce & 4 & 6.0 \\
\hline \multirow{4}{*}{ Education level } & No formal education & 11 & 16.4 \\
\hline & Primary school & 7 & 10.5 \\
\hline & Secondary school & 37 & 55.2 \\
\hline & College/University & 12 & 17.9 \\
\hline \multirow{4}{*}{ Work experience } & $<2$ years & 31 & 46.3 \\
\hline & $2-4$ years & 16 & 23.9 \\
\hline & 5-6 years & 9 & 13.4 \\
\hline & $>6$ years & 11 & 16.4 \\
\hline \multirow{5}{*}{ Job responsibility } & Cooking & 35 & 52.3 \\
\hline & Cleaning and washing dishes & 3 & 4.5 \\
\hline & Serving food & 17 & 25.4 \\
\hline & Preparation of food ingredients & 4 & 6.0 \\
\hline & Others (cashier, manager, etc.) & 8 & 11.9 \\
\hline \multirow{2}{*}{$\begin{array}{l}\text { Did you attend the Safe } \\
\text { Food Handling course? }\end{array}$} & No & 17 & 25.4 \\
\hline & Yes & 50 & 74.6 \\
\hline \multirow{3}{*}{$\begin{array}{l}\text { When did you attend the } \\
\text { Safe Food Handling course? }\end{array}$} & Never attend before & 17 & 25.4 \\
\hline & $\leq 3$ years ago & 29 & 43.3 \\
\hline & $>3$ years ago & 21 & 31.3 \\
\hline \multicolumn{2}{|c|}{ Total } & 67 & 100 \\
\hline
\end{tabular}


The food handlers demonstrated moderate overall knowledge of food safety (mean score $=$ $61.7 \pm 8.1 \%$ ). Of the six constructs on food safety knowledge tested, the respondents scored highest in the construct of personal hygiene (mean score $=97.7 \pm 11.4 \%$ ) but performed poorly in the construct of cross-contamination prevention and sanitation (mean score $=51.1 \pm 15.0 \%$ ) and foodborne pathogens (mean score $=19.6 \pm 25.1 \%$; Figure 1). Based on the questionnaires, the participants showed an overall good attitude, scoring an average of $51.9 \pm 4.2$ out of the total score of 57 (Table 2). Also, the participants had reported that they frequently practised safe food handling during food preparation, scoring an average of $53.2 \pm 5.5$ of the total score of 60 (Table 3).

Table 2. Participant food safety attitude scores.

\begin{tabular}{|c|c|c|c|c|}
\hline Item & Mean & SD & Min & Max \\
\hline \multicolumn{5}{|l|}{ Self-improvement } \\
\hline I would read more journals about food safety in order to enhance my food sanitation knowledge. & 3.5 & 0.9 & 1.0 & 4.0 \\
\hline I think by attending a sanitation seminar, it would increase my sanitation knowledge and ideas. & 3.9 & 0.4 & 1.0 & 4.0 \\
\hline I would attend food safety seminar to gain more food safety knowledge. & 3.8 & 0.5 & 1.0 & 4.0 \\
\hline $\begin{array}{l}\text { I think I do not need to attend food safety seminar because I think I have sufficient knowledge } \\
\text { about food safety. }\end{array}$ & 1.6 & 1.6 & 1.0 & 4.0 \\
\hline \multicolumn{5}{|l|}{ Food safety concern } \\
\hline Food handlers are responsible to prevent food poisoning. & 3.9 & 0.5 & 1.0 & 4.0 \\
\hline Government is responsible to prevent food poisoning. & 3.2 & 1.3 & 1.0 & 4.0 \\
\hline University is responsible to prevent food poisoning. & 3.3 & 1.2 & 1.0 & 4.0 \\
\hline Consumers are responsible to prevent food poisoning. & 3.4 & 1.1 & 1.0 & 4.0 \\
\hline Maintaining a clean cooking environment is a good way to control food safety. & 4.0 & 0.3 & 2.0 & 4.0 \\
\hline Self-checking of food safety is important to restaurants and institutions. & 3.8 & 0.4 & 2.0 & 4.0 \\
\hline
\end{tabular}

Table 3. Participant self-reported food safety practices.

\begin{tabular}{|c|c|c|c|c|}
\hline Item & Mean & SD & Min & Max \\
\hline Do you wash your hands before touching unwrapped raw foods? & 4.6 & 0.8 & 1.0 & 5.0 \\
\hline Do you wash your hands after touching unwrapped raw foods? & 4.6 & 0.9 & 1.0 & 5.0 \\
\hline Do you use gloves when you touch or distribute unwrapped foods? & 4.3 & 1.2 & 1.0 & 5.0 \\
\hline Do you use protective clothing (apron) when you touch or distribute unwrapped foods? & 4.6 & 1.0 & 1.0 & 5.0 \\
\hline Do you use mask when you touch or distribute unwrapped foods? & 2.8 & 1.5 & 1.0 & 5.0 \\
\hline Do you use cap when you touch or distribute unwrapped foods? & 4.5 & 1.2 & 1.0 & 5.0 \\
\hline Do you use different chopping board for raw meat and fresh produce (vegetables and fruit)? & 4.3 & 1.1 & 1.0 & 5.0 \\
\hline Do you wash and sanitise the working clothes? & 4.8 & 0.6 & 1.0 & 5.0 \\
\hline Do you use a different cloth or towel to dry plates? & 4.6 & 1.0 & 1.0 & 5.0 \\
\hline Do you wash and sanitise the knife after chopping raw chicken or meat? & 4.8 & 0.4 & 4.0 & 5.0 \\
\hline Do you use clean and washed plate for ready-to-eat foods? & 4.9 & 0.3 & 4.0 & 5.0 \\
\hline Do you work when you are sick (flu, cold, diarrhoea, coughing, etc.)? & 4.3 & 1.1 & 1.0 & 5.0 \\
\hline
\end{tabular}


It is important to wash hands after touching money. It is important to wash hands before preparing meals. It is important to wash hands after using toilets. It is important to wash hands after handling raw meats or poultry. It is important to wash hands after touching the body. It is important to wash hands after sneezing.

It is important to wash hands after clearing tables. It is important to wash hands after handling the garbage. It is necessary to wear gloves before touching ready to eat food products. Duration of hand washing is at least 20 seconds.

Use the same knife to cut raw meat or poultry and vegetables. Wash the knife used to cut raw meat or poultry with hot water before using it to cut vegetables. Wash the knife used to cut raw meat or poultry with water and soap before using it to cut vegetables.

Wash the knife used to cut raw meat or poultry with water and soap then apply sanitizer before using it to cut vegetables. Change knife to cut raw meat or poultry and to cut vegetables. Use the same cutting board to cut raw meat or poultry and to cut vegetables. Wash the cutting board used to cut raw meat or poultry with hot water before using it to cut vegetables. Wash the cutting board used to cut raw meat or poultry with water and soap before using it to cut vegetables.

Wash the cutting board used to cut raw meat or poultry with water and soap then apply sanitizer before using it to cut vegetables. Wipe the cutting board used to cut raw meat or poultry with a piece of cloth before using it to cut vegetables.

Change cutting board to cut raw meat or poultry and to cut vegetables. Wash the food contact surface with water and soap then apply a sanitizer is the most effective method in cleaning and saritize food contact surfaces.

Thaw frozen raw meat or poultry on the kitchen counter in an open container. Thaw frozen raw meat or poultry in the refiigerator. Thaw frozen raw meat or poultry under running tap water. Refrigerator operating temperature is $1-5^{\circ} \mathrm{C}$. Freezer operating temperature is $-18^{\circ} \mathrm{C}$. Store leftover on steam table. Store leftover in the refrigerator. Store leftover on the shelf in the kitchen.

Cooked rice, which was stored incorrectly, may contain germs that can make people sick. If raw chicken has been stored at a temperature that is too warm, but then is properly cooked to the cortect internal temperature, it becomes safe to eat.

Sneezing would affect food safety. Coughing would affect food safety. Hypertension would affect food safety. Covered wound in the hand with wearing a glove would affect food safety. Fever would affect food safety. Sore throat would affect food safety.

Vomiting would affect food safety. Diarrhea would affect food safety. Smoking would affect food safety

When you are suffering from vomitting or diarrhea but don't feel really sick, you are allowed to handle RTE foods on that day.

Abdominal pain is a symptom of food borne illnesses. Diarthea is a symptom of food borne illnesses. Vomiting is a symptom of food borne illnesses. Nausea is a symptom of food borne illnesses. Headache is a symptom of food borne illnesses. Hypertension is a symptom of food borne illnesses. Hypoglycenia is a symptom of food borne illnesses. Pain in the bote is a symptom of food borne illnesses. Coughing or sneezing is a symptom of food borne illnesses.

Have you heard of Salmonella? Have you heard of Listeria monocytogenes? Have you heard of Staphylococcus aureus? Have you heard of Bacillis cereus ? Have you heard of $E$, coli $157: \mathrm{H} 7$ ? Have you heard of Clostridium perfringens ? Have you heard of Campylobacter jejuni ?

Have you heard of Shigella? Have you heard of Hepatitis?

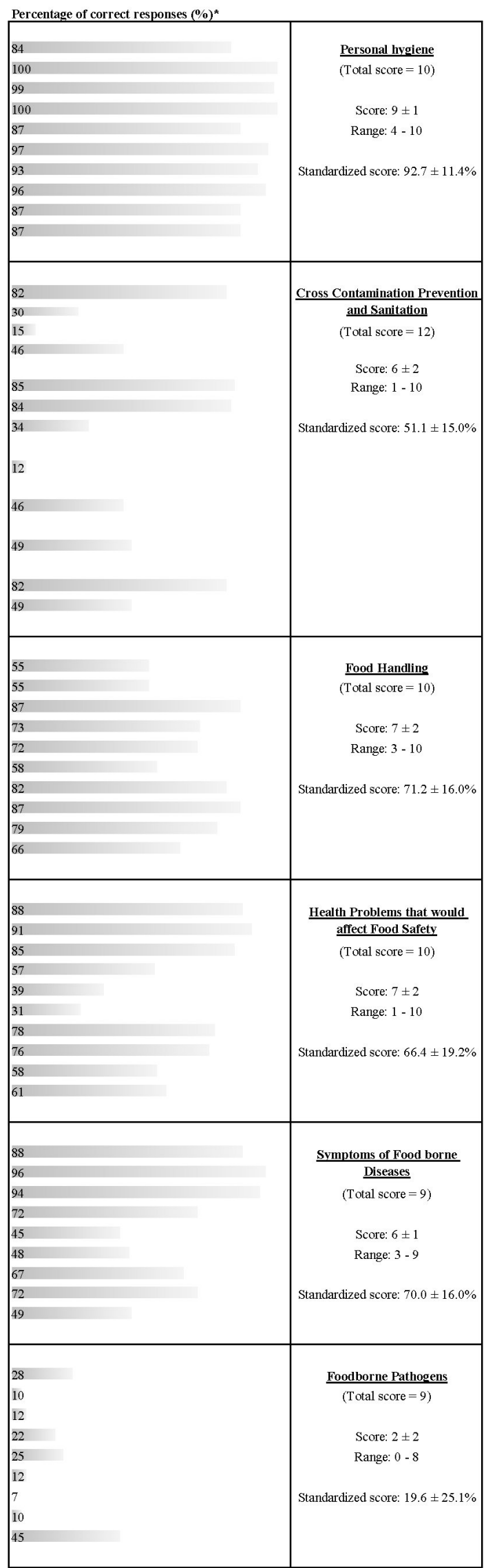

(* except for construct of foodborne pathogens, in which the bars indicate percentage of "yes" response.)

Figure 1. Percentage of the correct answers on food safety knowledge scored by 67 food handlers. 
This study showed that the education level, working experience, and safe food handling course had different degrees of impact on food safety knowledge and attitudes of food handlers (Table 4). It is interesting to note that those who had not received any formal education performed better than those who had received primary education. Nonetheless, it was found that those who had secondary education and above scored significantly higher on food safety items related to food handling $(p<0.05$; Table 4); and only food handlers with tertiary education knew more about foodborne pathogens than the rest $(p<0.05$; Table 4$)$. On the other hand, food handlers who had more working experience in the food service industry had a better overall food safety knowledge (more than 6 years $>5-6$ years $>2-4$ years $\geq 2$ years, $p<0.05$ ) than food handlers with lesser experience. From the questionnaire, even though the safe food handling course did not significantly improve the food safety knowledge, those who had attended the course performed slightly better than those who had not attended the course (Table 4). Most importantly, the safe food handling course had a significant positive impact on the attitudes toward food safety.

Ironically, the food handlers who had a non-compliant coliform count $\left(\geq 20 \mathrm{CFU} / \mathrm{cm}^{2}\right)$ claimed to use gloves more frequently when touching or distributing unwrapped foods than those who had a compliance count of coliform (Table 6). On the contrary, the food handlers who were detected with the presence of Salmonella attested that they were less frequent in using caps while handling food $(4.2 \pm 1.6, n=24, p<0.05)$ than those who had negative detection for in the presence of Salmonella. Furthermore, the respondents who had of an exceeded limit of total aerobic bacteria $\left(\geq 20 \mathrm{CFU} / \mathrm{cm}^{2}\right)$ on their hands declared that they wash their hands before touching the unwrapped foods $(4.7 \pm 0.5$, $n=27, p<0.05)$ more frequently. The food handlers who has coliform count exceeded the threshold reported that they sanitise their working cloths more frequently $(5.0 \pm 0.0, n=15, p<0.05)$. 
Table 4. Attribution of food safety knowledge, attitude, and self-reported scores to educational level, work experience, and safe food handling course of participants $(n=67)$.

\begin{tabular}{|c|c|c|c|c|c|c|c|c|c|c|c|c|c|}
\hline \multirow{3}{*}{ Construct } & \multicolumn{4}{|c|}{ Education Level } & \multicolumn{4}{|c|}{ Work Experience } & \multicolumn{2}{|c|}{$\begin{array}{l}\text { Did You Attend the Safe } \\
\text { Food Handling Course? }\end{array}$} & \multicolumn{3}{|c|}{$\begin{array}{l}\text { When Did You Attend the } \\
\text { Safe Food Handling Course? }\end{array}$} \\
\hline & $\begin{array}{l}\text { No Formal } \\
\text { Education }\end{array}$ & $\begin{array}{c}\text { Primary } \\
\text { School }\end{array}$ & $\begin{array}{l}\text { Secondary } \\
\text { School }\end{array}$ & College/University & $\leq 2$ Years & 2-4 Years & 5-6 Years & $>6$ Years & No & Yes & $\begin{array}{c}\text { Never } \\
\text { Attended }\end{array}$ & $\begin{array}{c}\leq 3 \text { Years } \\
\text { Ago }\end{array}$ & $\begin{array}{c}>3 \text { Years } \\
\text { Ago }\end{array}$ \\
\hline & $(n=11)$ & $(n=7)$ & $(n=37)$ & $(n=12)$ & $(n=31)$ & $(n=16)$ & $(n=9)$ & $(n=11)$ & $(n=17)$ & $(n=50)$ & $(n=17)$ & $(n=29)$ & $(n=21)$ \\
\hline \multicolumn{14}{|l|}{ Knowledge (\%) } \\
\hline Personal hygiene & $95.5^{\mathrm{a}}$ & $87.1^{\mathrm{a}}$ & $94.3^{\mathrm{a}}$ & $88.3^{\mathrm{a}}$ & $92.3^{\mathrm{a}}$ & $91.3^{\mathrm{a}}$ & $94.4^{\mathrm{a}}$ & $94.6^{\mathrm{a}}$ & $90.0^{\mathrm{a}}$ & $93.6^{\mathrm{a}}$ & $90.0^{\mathrm{a}}$ & $94.8^{\mathrm{a}}$ & $91.9^{\mathrm{a}}$ \\
\hline $\begin{array}{l}\text { Cross contamination } \\
\text { prevention and sanitation }\end{array}$ & $49.2^{\mathrm{a}}$ & $60.7^{\mathrm{a}}$ & $49.8^{\mathrm{a}}$ & $53.5^{\mathrm{a}}$ & $50.5^{\mathrm{a}}$ & $53.1^{\mathrm{a}}$ & $50.9^{\mathrm{a}}$ & $52.3^{\mathrm{a}}$ & $48.0^{\mathrm{a}}$ & $52.7^{\mathrm{a}}$ & $48.0^{\mathrm{a}}$ & $53.5^{\mathrm{a}}$ & $51.6^{\mathrm{a}}$ \\
\hline Food handling & $66.4^{a, b}$ & $52.9^{\text {a }}$ & $75.1^{\mathrm{b}}$ & $74.2^{b, c}$ & $73.2 \mathrm{a}, \mathrm{b}$ & $61.3^{\mathrm{a}}$ & $66.7^{a, b}$ & $83.6^{\mathrm{b}}$ & $73.5^{\mathrm{a}}$ & $70.4^{\mathrm{a}}$ & $73.5^{\mathrm{a}}$ & $68.3^{\mathrm{a}}$ & $73.3^{\mathrm{a}}$ \\
\hline $\begin{array}{l}\text { Health problems that } \\
\text { would affect food safety }\end{array}$ & $62.7^{\mathrm{a}}$ & $54.3^{\mathrm{a}}$ & $69.2^{\mathrm{a}}$ & $68.3^{\mathrm{a}}$ & $61.9^{\mathrm{a}}$ & $63.1^{\mathrm{a}}$ & $73.3^{\mathrm{a}}$ & $78.2^{\mathrm{a}}$ & $72.9^{\mathrm{a}}$ & $64.2^{\mathrm{a}}$ & $72.9^{\mathrm{a}}$ & $60.0^{\mathrm{a}}$ & $70.0^{\mathrm{a}}$ \\
\hline $\begin{array}{l}\text { Symptoms of } \\
\text { foodborne diseases }\end{array}$ & $78.8^{\mathrm{a}}$ & $66.7^{\mathrm{a}}$ & $66.1^{\mathrm{a}}$ & $75.9^{\mathrm{a}}$ & $66.7^{\mathrm{a}}$ & $72.2^{\mathrm{a}}$ & $70.4^{\mathrm{a}}$ & $75.8^{\mathrm{a}}$ & $66.0^{\mathrm{a}}$ & $71.3^{\mathrm{a}}$ & $66.0^{\mathrm{a}}$ & $68.6^{\mathrm{a}}$ & $75.1^{\mathrm{a}}$ \\
\hline Foodborne pathogens & $6.1^{\mathrm{a}}$ & $25.4^{a, b}$ & $16.2^{\mathrm{a}}$ & $38.9^{\mathrm{b}}$ & $14.7^{\mathrm{a}}$ & $19.4^{\mathrm{a}}$ & $19.8^{\mathrm{a}}$ & $33.3^{\mathrm{a}}$ & $4.6^{\mathrm{a}}$ & $24.7^{\mathrm{b}}$ & $4.6^{\mathrm{a}}$ & $23.8^{\mathrm{b}}$ & $25.9^{\mathrm{b}}$ \\
\hline Overall knowledge score & $60.0^{\mathrm{a}}$ & $58.3^{\mathrm{a}}$ & $62.1^{\mathrm{a}}$ & $66.4^{\mathrm{a}}$ & $60.2^{\mathrm{a}}$ & $60.3^{a}$ & $62.8^{a, b}$ & $69.5^{\mathrm{b}}$ & $59.6^{\mathrm{a}}$ & $63.0^{\text {a }}$ & $59.6^{\mathrm{a}}$ & $61.7^{\mathrm{a}}$ & 64.7 a \\
\hline \multicolumn{14}{|l|}{ Food safety attitude } \\
\hline Self-improvement & $3.5^{a, b}$ & $3.5^{a, b}$ & $3.7^{\mathrm{a}}$ & $3.3^{\mathrm{b}}$ & $3.6^{\mathrm{a}}$ & $3.5^{\mathrm{a}}$ & $3.5^{\mathrm{a}}$ & $3.9^{\mathrm{a}}$ & $3.6^{\mathrm{a}}$ & $3.6^{\mathrm{a}}$ & $3.6^{\mathrm{a}}$ & $3.6^{\mathrm{a}}$ & $3.5^{\mathrm{a}}$ \\
\hline Food safety concern & $3.5^{\mathrm{a}}$ & $3.6^{\mathrm{a}}$ & $3.4^{\mathrm{a}}$ & $3.5^{\mathrm{a}}$ & $3.4^{\mathrm{a}}$ & $3.5^{\mathrm{a}}$ & $3.5^{\mathrm{a}}$ & $3.4^{\mathrm{a}}$ & $3.1^{\mathrm{a}}$ & $3.5^{\mathrm{b}}$ & $3.1^{\mathrm{a}}$ & $3.5^{\mathrm{b}}$ & $3.5^{\mathrm{b}}$ \\
\hline Overall attitude score & $3.5^{\mathrm{a}}$ & $3.6^{\mathrm{a}}$ & $3.5^{\mathrm{a}}$ & $3.4^{\mathrm{a}}$ & $3.4^{\mathrm{a}}$ & $3.5^{\mathrm{a}}$ & $3.5^{\mathrm{a}}$ & $3.6^{\mathrm{a}}$ & $3.3^{\mathrm{a}}$ & $3.5^{\mathrm{b}}$ & $3.3^{\mathrm{a}}$ & $3.6^{\mathrm{b}}$ & $3.5^{\mathrm{a}, \mathrm{b}}$ \\
\hline \multicolumn{14}{|l|}{ Self-reported practices } \\
\hline Overall practices score & $4.3^{\mathrm{a}}$ & $4.2^{\mathrm{a}}$ & $4.2^{\mathrm{a}}$ & $4.0^{\mathrm{a}}$ & $4.3^{\mathrm{a}}$ & $4.2^{\mathrm{a}}$ & $4.0^{\mathrm{a}}$ & $4.3^{\mathrm{a}}$ & $4.3^{\mathrm{a}}$ & $4.2^{\mathrm{a}}$ & $4.3^{\mathrm{a}}$ & $4.2^{\mathrm{a}}$ & $4.1^{\mathrm{a}}$ \\
\hline
\end{tabular}

The values expressed in the column for the knowledge section are the mean percentage of each category in respect to each construct of KAP while the values expressed in the food safety attitudes and self-reported practices are the mean score obtained from the questionnaire analysis. Values in the same row and subtable not sharing the same superscript $\left({ }^{a}, b, c\right)$ are significantly different at $p<0.05$ in the two-sided test of equality for column means. Cells with no superscript are not included in the test. Tests assume equal variances and are adjusted for all pairwise comparisons within a row of each innermost subtable using the Bonferroni correction. 
Hand hygiene assessment of the food handlers participating in this study revealed that $65 \%$ ( $n=55$ ) of them had an aerobic bacterial count exceeding the threshold of $\geq 20 \mathrm{CFU} / \mathrm{cm}^{2}$ based on Sneed et al. [26] and Tan et al. [24]. Approximately 35\% $(n=30)$ had exceeded the standard coliform count $\left(\geq 10 \mathrm{CFU} / \mathrm{cm}^{2}\right.$; Table 5). Moreover, Salmonella, V. cholerae and V. parahaemolyticus were detected in $41(48 \%), 2(2 \%)$, and $1(1 \%)$ of the 85 food handlers examined (Table 5). The number of Salmonella present on the contaminated hands ranged from 3 to $150 \mathrm{MPN} /$ hand (Table 5).

Table 5. Performance of participants' hand hygiene based on aerobic bacteria, coliforms and E. coli, S. aureus count and the detection of Salmonella, V. cholerae and V. parahaemolyticus.

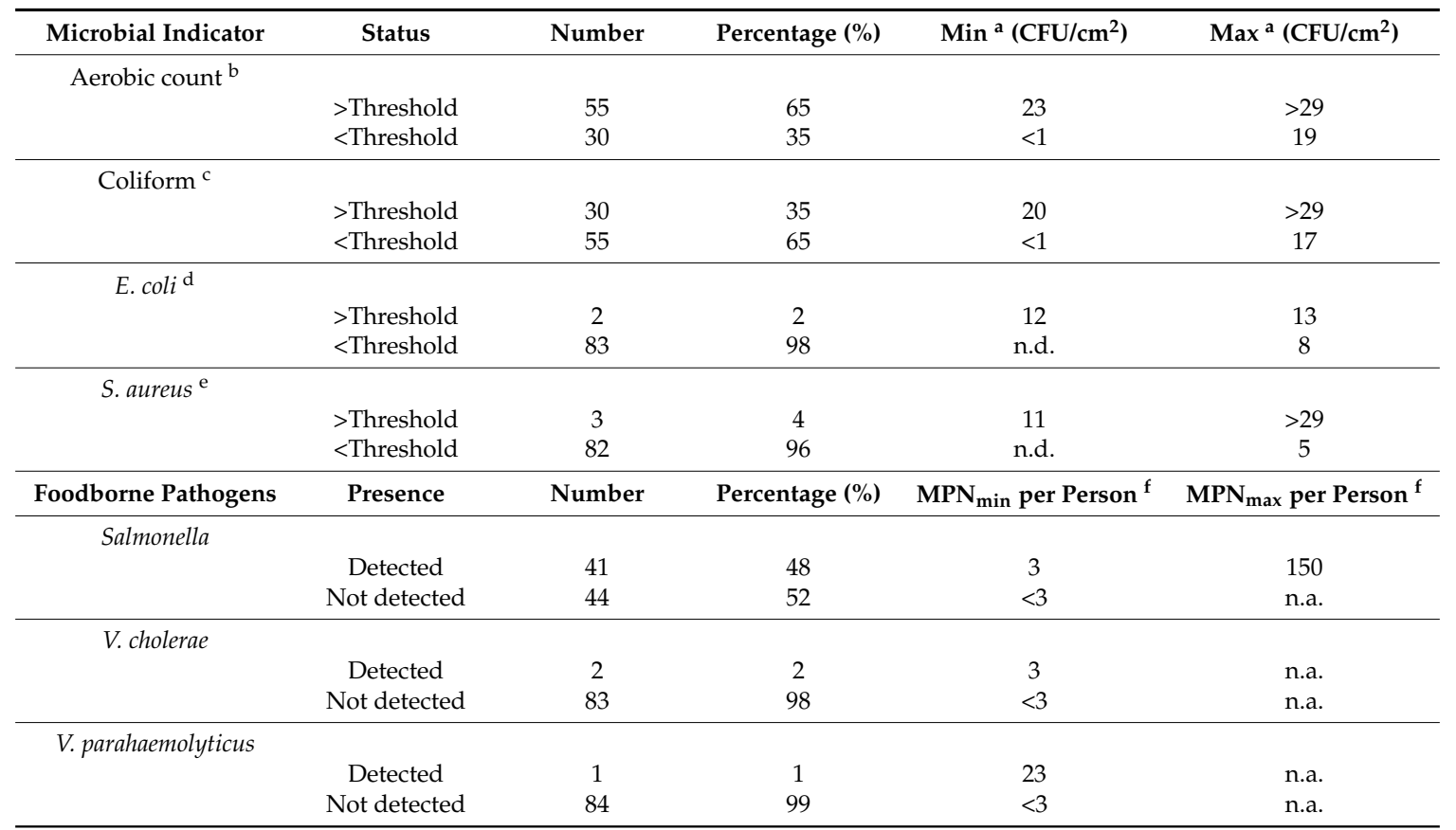

n.d.: Not detected or below detection limit; n.a.: Not applicable; MPN: Most probable number; ${ }^{\text {a }}$ The minimum (Min) and maximum (Max) CFU/ $\mathrm{cm}^{2}$; b Aerobic count threshold based on Tan et al. [25] and Sneed et al. [26], which is $\geq 20 \mathrm{CFU} / \mathrm{cm}^{2}$; ${ }^{c}$ Coliform count threshold based on Tan et al. [25] and Sneed et al. [26], which is $\geq 20 \mathrm{CFU} / \mathrm{cm}^{2}$; ${ }^{\mathrm{d}}$ E. coli count threshold based on Tan et al. [25] and Sneed et al. [26], which is $\geq 10 \mathrm{CFU} / \mathrm{cm}^{2}$; e S. aureus count threshold based on Tan et al. [25] and Sneed et al. [26], which is $\geq 10 \mathrm{CFU} / \mathrm{cm}^{2} ;{ }^{\mathrm{f}} \mathrm{The}$ minimum $\left(\mathrm{MPN}_{\min }\right)$ and maximum $\left(\mathrm{MPN}_{\max }\right) \mathrm{MPN}$ value per person. 
Table 6. Self-reported practices vs. microbial contamination on food handlers' hands.

\begin{tabular}{|c|c|c|c|c|c|c|c|c|c|}
\hline \multirow[b]{2}{*}{ Item } & \multicolumn{2}{|c|}{ Aerobic Count ${ }^{a}$} & \multicolumn{2}{|c|}{ Coliforms $^{a}$} & \multirow{2}{*}{$\begin{array}{c}\text { E. coli }{ }^{\mathrm{b}} \\
<\text { Threshold } \\
(n=41)\end{array}$} & \multicolumn{2}{|c|}{ S. aureus $^{\text {a }}$} & \multicolumn{2}{|c|}{ Salmonella } \\
\hline & $\begin{array}{l}>\text { Threshold } \\
(n=27)\end{array}$ & $\begin{array}{c}<\text { Threshold } \\
(n=14)\end{array}$ & $\begin{array}{l}>\text { Threshold } \\
\quad(n=15)\end{array}$ & $\begin{array}{c}<\text { Threshold } \\
(n=26)\end{array}$ & & $\begin{array}{c}>\text { Threshold } \\
(n=2)\end{array}$ & $\begin{array}{c}<\text { Threshold } \\
(n=39)\end{array}$ & $\begin{array}{l}>\text { Threshold } \\
(n=24)\end{array}$ & $\begin{array}{c}\text { <Threshold } \\
\quad(n=17)\end{array}$ \\
\hline $\begin{array}{l}\text { Do you wash your hands before touching } \\
\text { unwrapped raw foods? }\end{array}$ & $4.7 \pm 0.5$ & $4.1 \pm 0.9$ & $4.7 \pm 0.5$ & $4.4 \pm 0.9$ & $4.5 \pm 0.7$ & $5.0 \pm 0.0$ & $4.5 \pm 0.8$ & $4.7 \pm 0.6$ & $4.4 \pm 0.8$ \\
\hline $\begin{array}{l}\text { Do you wash your hands after touching } \\
\text { unwrapped raw foods? }\end{array}$ & $4.6 \pm 1.0$ & $4.6 \pm 0.9$ & $4.4 \pm 1.2$ & $4.6 \pm 0.8$ & $4.6 \pm 1.0$ & $5.0 \pm 0.0$ & $4.5 \pm 1.0$ & $4.4 \pm 1.2$ & $4.6 \pm 0.8$ \\
\hline $\begin{array}{l}\text { Do you use gloves when you touch or distribute } \\
\text { unwrapped foods? }\end{array}$ & $4.3 \pm 1.2$ & $3.9 \pm 1.2$ & $4.7 \pm 0.7$ & $3.9 \pm 1.4$ & $4.2 \pm 1.2$ & $5.0 \pm 0.0$ & $4.2 \pm 1.2$ & $4.2 \pm 1.4$ & $4.2 \pm 1.1$ \\
\hline $\begin{array}{l}\text { Do you use protective clothing (apron) when you } \\
\text { touch or distribute unwrapped foods? }\end{array}$ & $4.4 \pm 1.2$ & $4.6 \pm 0.7$ & $4.1 \pm 1.5$ & $4.7 \pm 0.7$ & $4.5 \pm 1.1$ & $5.0 \pm 0.0$ & $4.5 \pm 1.1$ & $4.3 \pm 1.2$ & $4.6 \pm 1.0$ \\
\hline $\begin{array}{l}\text { Do you use mask when you touch or distribute } \\
\text { unwrapped foods? }\end{array}$ & $2.6 \pm 1.4$ & $2.5 \pm 1.2$ & $3.1 \pm 1.5$ & $2.3 \pm 1.1$ & $2.6 \pm 1.3$ & $3.5 \pm 0.7$ & $2.5 \pm 1.3$ & $2.6 \pm 1.4$ & $2.8 \pm 1.3$ \\
\hline $\begin{array}{l}\text { Do you use cap when you touch or distribute } \\
\text { unwrapped foods? }\end{array}$ & $4.7 \pm 1.1$ & $4.6 \pm 1.1$ & $4.7 \pm 1.0$ & $4.7 \pm 1.1$ & $4.7 \pm 1.1$ & $5.0 \pm 0.0$ & $4.6 \pm 1.1$ & $4.2 \pm 1.6$ & $4.9 \pm 0.3$ \\
\hline $\begin{array}{l}\text { Do you use different chopping board for raw meat } \\
\text { and fresh produce (vegetables and fruit)? }\end{array}$ & $4.3 \pm 1.2$ & $4.0 \pm 0.9$ & $4.4 \pm 1.2$ & $4.1 \pm 1.1$ & $4.2 \pm 1.1$ & $5.0 \pm 0.0$ & $4.2 \pm 1.1$ & $4.5 \pm 0.8$ & $4.2 \pm 1.1$ \\
\hline Do you wash and sanitise the working clothes? & $4.9 \pm 0.3$ & $4.4 \pm 1.1$ & $5.0 \pm 0.0$ & $4.6 \pm 0.9$ & $4.7 \pm 0.7$ & $5.0 \pm 0.0$ & $4.7 \pm 0.7$ & $4.8 \pm 0.4$ & $4.6 \pm 0.9$ \\
\hline Do you use a different cloth or towel to dry plates? & $4.5 \pm 1.2$ & $4.3 \pm 1.1$ & $4.7 \pm 1.0$ & $4.3 \pm 1.2$ & $4.4 \pm 1.2$ & $5.0 \pm 0.0$ & $4.4 \pm 1.2$ & $4.6 \pm 0.9$ & $4.5 \pm 1.1$ \\
\hline $\begin{array}{l}\text { Do you wash and sanitise the knife after chopping } \\
\text { raw chicken or meat? }\end{array}$ & $4.9 \pm 0.3$ & $4.4 \pm 0.5$ & $4.9 \pm 0.3$ & $4.7 \pm 0.5$ & $4.8 \pm 0.4$ & $5.0 \pm 0.0$ & $4.8 \pm 0.4$ & $4.8 \pm 0.4$ & $4.7 \pm 0.5$ \\
\hline Do you use clean and washed plate for RTE foods? & $4.9 \pm 0.3$ & $4.9 \pm 0.3$ & $4.9 \pm 0.3$ & $4.9 \pm 0.3$ & $4.9 \pm 0.3$ & $5.0 \pm 0.0$ & $4.9 \pm 0.3$ & $4.9 \pm 0.3$ & $4.9 \pm 0.3$ \\
\hline $\begin{array}{l}\text { Do you work when you are sick (flu, cold, } \\
\text { diarrhoea, coughing, etc.)? }\end{array}$ & $4.3 \pm 1.2$ & $3.6 \pm 1.1$ & $4.5 \pm 0.7$ & $3.8 \pm 1.3$ & $4.0 \pm 1.2$ & $3.0 \pm 2.8$ & $4.1 \pm 1.1$ & $4.2 \pm 1.3$ & $4.0 \pm 1.1$ \\
\hline
\end{tabular}

The values are the mean score obtained from questionnaire analysis. Results are based on two-sided tests with significance level at 0.05 . The significant pair is highlighted in bold.

${ }^{a}$ Threshold of aerobic bacteria count, coliforms, E. coli and S. aureus were based on Tan et al. [25] and Sneed et al. [26], which is $\geq 20 \mathrm{CFU} / \mathrm{cm}^{2} ;{ }^{\mathrm{b}} t$-test was not conducted as the one of

the sample size is too little for confident statistical analysis. 


\section{Discussion}

In Malaysia, the food service industry has shown an increasing trend of hiring foreign labourers to work as servants, stewards, and cooks to prepare foods. The actual number of foreign food workers working in Malaysia is not known because most of them are working on a contract basis. The use of contract workers in food premises has raised the public concern about food operations' ability to ensure food safety [29]. Our study reflected the scenario where there are more foreign food handlers $(61.2 \%)$ working in the food premises than the locals (Table 1). Other similar studies conducted in another part of Malaysia have also reported the same scenario [19,20,29]. One of the main concerns of having more foreign food handlers in Malaysia is the effectiveness of the safe food handling course which is conducted in either Malay or English languages. The majority of the foreign food handlers are from India, Pakistan, Nepal, and Cambodia and their command of English is low and therefore it is presumed that the safe food handling course will be of little impact in instilling proper food safety practices among the food handlers. However, our findings did not reflect such a scenario. Although the improvement of knowledge performance was not significant between those who had attended the course and those who had not, the safe food handling course showed a significant impact on instilling positive food safety attitudes, particularly regarding food safety concerns among the respondents who were predominantly foreigners (Table 4). Nonetheless, more detailed work is required to review the effectiveness of the national safe food handling course, particularly regarding the foreign food workers. An easy-to-understand module such as those based on illustrations could be more efficient in delivering the knowledge to food handlers of different backgrounds and education levels.

Of the six constructs assessed on food safety knowledge, the food handlers who participated in this study demonstrated good knowledge of personal hygiene (mean score: $97.7 \pm 11.4 \%$ ) but not on cross-contamination (mean score: $51.1 \pm 15.0 \%$ ). Our finding was in agreement with other studies in Malaysia [19]. We believe that this scenario is a reflection of the current safe food handling course in Malaysia which focuses on the personal hygiene of food handlers while less emphasis is given to prevention of cross-contamination. The food handlers demonstrated poor knowledge of foodborne pathogens (19.6 $\pm 25.1 \%)$. This finding is supported by Liu et al. [30] Based on the study conducted by Saad and co-workers [29] on hygiene practices among food handlers in governmental institutions in Malaysia, about 30\% of the food handlers commented that the safe food handling course failed to improve their knowledge at work. However, our study suggested that the food safety handling course could have significantly improved the awareness of food handlers, particularly regarding foodborne pathogens (Table 4). Nevertheless, the findings indicated that the contents of the safe food handling course need to be reviewed and improved.

The education level of food handlers is generally perceived as one of the factors that compromised the food safety and hygiene. Although we have observed an improvement in the food safety knowledge among those with tertiary education, food handlers with lower education levels, particularly those who had no formal education outperformed those with higher education (Table 4). For instance, the food handlers without formal education outperformed others on personal hygiene knowledge (Table 4). These findings are further supported by the Pichler et al. [23], McIntyre et al. [31], Lynch et al. [32] and Toh and Birchenough [33]. Working experience, on the other hand, was found to have a significant impact on the overall food safety knowledge among the respondents in this study (Table 4). Saad and co-workers [29] also reported a similar observation.

In this study, a microbial assessment to examine the hand hygiene of the participating food handlers was conducted to obtain a better insight into the current food safety practices in food premises. The microbiological hygiene assessment reflects the real practices of proper safe food handling and at the same time could be used to validate the self-reported practices. The findings from our study were not encouraging as many food handlers were found to have microbial counts exceeding the standards (Table 5). More alarmingly, Salmonella was detected on the hands of about half of the participated food handlers. These food handlers could be the asymptomatic carriers for Salmonella transmission as Salmonella can remain in a carrier state up to 300 days after infection [34]. 
This raises many public health concerns, as most of the food handlers were not wearing gloves during food handling, as we observed during the study. This situation could eventually increase the risk of food poisoning.

Other studies have reported that provision of food safety and hygiene knowledge is not necessarily translated into safe food behaviour or practice [10,35-37]. Similarly, our results indicated that the generally moderate performance on food safety knowledge was not reflected in the microbial hand hygiene assessment. For instance, the respondents who claimed that they often wore gloves had coliform counts exceeding the threshold (Table 6). Our observation did not suggest that the food handlers often wore gloves. This scenario could eventually increase the risk of coliform contamination in foods. Overall, the findings suggested that the safe food handling course did, in fact, impart some knowledge and awareness of food safety, but failed to change the safe food behaviour among the food handlers. According to Worsfold et al. [38], behaviour change in safe food handling can be attained when the knowledge and skills learned are being rehearsed and used. Continual training and management support are important elements in the transfer of knowledge into behaviour [39]. In this case, further studies are required to understand the factors that have limited the transfer of knowledge into safe food practice among food handlers.

\section{Conclusions}

Although the food handlers had a moderate level of food safety knowledge with a good attitude, and self-reported practices, the poor performance in the hand hygiene assessment indicated a failure in actually practising safe food handling in their job. The contaminated hands of food handlers could easily transmit foodborne diseases through cross-contamination of food products. The current findings indicated a need to review the effectiveness of the current national safe food handling course, not just to improve the effectiveness to disseminate food safety knowledge and attitudes, but also to induce a real change in safe food handling behavior among food handlers by taking into consideration the multi-cultural and education level of food handlers in Malaysia. It is apparent from this study that a good knowledge in food safety is not indicative of food safety practice in the real world. Studies are required to look into the factors that inhibit the transfer of knowledge into food safety behaviour in Malaysia so that an effective food safety policy can be put in place.

There are several limitations in this research. These results only relied on the very limited number of food handlers who took part in this study and therefore the observation or findings in the study should not be extrapolated to represent the scenario in Malaysia. However, this study is exploratory in nature and serves as a pilot study for a nationwide study of the relationship between hand sanitation and the KAP of food handlers. Future studies should involve a collaboration with the government and a larger population of food handlers so that the authority can establish a more comprehensive approach to ensure food safety.

Acknowledgments: This study was fully funded by University Malaya Research Grant (RP003C-13BIO and RP003A-13BIO). Hui Key Lee was supported by MOHE MyBrain scholarship. We thank Siti Sofea and Siti Azwani for the assistance in collecting samples and questionnaires.

Author Contributions: Hui Key Lee performed the experiments, analysed data and drafted the manuscript. Hishamuddin Abdul Halim involved in experimental design. Kwai Lin Thong provided the research instruments and edited the manuscript. Lay Ching Chai designed the experiments, contributed the research materials, cross checked the analysed data and edited manuscript.

Conflicts of Interest: The authors declare no conflict of interest.

\section{References}

1. World Health Organization (WHO). Food Safety; WHO: Geneva, Switzerland, 2015. Available online: http://www.who.int/mediacentre/factsheets/fs399/en/ (accessed on 19 October 2016).

2. Ministry of Health (MOH). Health Facts 2014; MOH: Putrajaya, Malaysia, 2014.

3. Ministry of Health (MOH). Annual Report 2007; MOH: Putrajaya, Malaysia, 2007. 
4. Ministry of Health (MOH). The National Level 2014 Clean, Safe and Healthy Canteen Award; Department of Food Safety and Food Quality, Ed.; MOH: Putrajaya, Malaysia, 2014.

5. Ministry of Health (MOH). Annual Report 2010; MOH: Putrajaya, Malaysia, 2012.

6. Michaels, B.; Keller, C.; Belvins, M.; Paoli, G.; Ruthman, T.; Todd, E.; Griffith, C.J. Prevention of food worker transmission of foodborne pathogens: Risk assessment and evaluation of effective hygiene intervention strategies. Food Serv. Technol. 2004, 4, 31-49. [CrossRef]

7. Lunestad, B.T.; Borlaug, K. Persistence of Salmonella enterica serovar agona in oil or fish feed production. J. Aquacult. Feed Sci. Nutr. 2009, 1, 73-77.

8. Olsen, S.J.; Hansen, G.R.; Bartlett, L.; Fitzgerald, L.; Sonder, A.; Manjrekar, R.; Riggs, T.; Kim, J.; Flahart, R.; Pezzin, G.; et al. An outbreak of Campylobacter jejuni infection associated with food handler contamination; the use of pulsed-field gel electrophoresis. J. Infect. Dis. 2001, 183, 164-167. [CrossRef] [PubMed]

9. Quiroz, E.S.; Bern, C.; MacArthur, J.R.; Xiao, L.; Fletcher, M.; Arrowood, M.J.; Shay, D.K.; Levy, M.E.; Glass, R.I.; Lal, A. An outbreak of cryptosporidiosis linked to a food handler. J. Infect. Dis. 2000, 181, 695-700. [CrossRef] [PubMed]

10. Angelillo, I.F.; Viggiani, N.M.; Rizzo, L.; Bianco, A. Food handlers and foodborne diseases: Knowledge, attitudes, and reported behavior in Italy. J. Food Prot. 2000, 63, 381-385. [CrossRef] [PubMed]

11. Scarborough, M.F. Hand Washing in Georgia's Public Schools-A Community Needs Assessment and Intervention Study. Master's Thesis, Emory University, Atlanta, GA, USA, May 2002.

12. Curtis, V.; Cairncross, S. Effect of washing hands with soap on diarrhea risk in the community: A systemic review. Lancet Infect. Dis. 2003, 3, 275-281. [CrossRef]

13. World Health Organization. World Health Organization. Evidence of hand hygiene to reduce transmission and infections by multidrug resistant organisms in health-care settings. In WHO Guidelines on Hand Hygiene in Health Care; Clean Care is Safer Care Team, Ed.; WHO: Geneva, Switzerland, 2009.

14. Gibson, L.L.; Rose, J.B.; Haas, C.N.; Gerba, C.P.; Rusin, P.A. Quantitative assessment of risk reduction from hand washing with antibacterial soaps. J. Appl. Microbiol. 2002, 92 (Suppl. S1), 136S-143S. [CrossRef] [PubMed]

15. Chinakwe, E.C.; Nwogwugwu, N.U.; Nwachukwu, I.N.; Okorondu, S.I.; Onyemekara, N.N.; Ndubuisi-Nnaji, U.U. Microbial quality and public health implications of hand-wash water samples of public adults in Owerri, South-east Nigeria. Int. Res. J. Microbiol. 2013, 3, 144-146.

16. Soares, L.S.; Almeida, R.C.C.; Cerqueira, E.S.; Carvalho, J.S.; Nunes, I.L. Knowledge, attitudes and practices in food safety and the presence of coagulase-positive staphylococci on hands of food handlers in the schools of Camaçari, Brazil. Food Control 2012, 27, 206-213. [CrossRef]

17. Perez-Rodriguez, F.; Valero, A.; Carrasco, E.; Garcia, R.M.; Zurera, G. Understanding and modelling bacterial transfer to foods: A review. Trends Food Sci. Technol. 2008, 19, 131-144. [CrossRef]

18. Noor-Azira, A.-M.; Mohammad-Faid, A.-R.; Shuhaimi, M.; Syafinaz, A.-N.; Hamat, A.H.R.A.; Malina, O. Knowledge, attitude and practices regarding food hygiene and sanitation of food handlers in Kuala Pilah, Malaysia. Food Control 2012, 27, 289-293.

19. Norrakiah, A.S.; Siow, O.N. Knowledge, attitudes and practices of food handlers on food safety in food service operations at the Universiti Kebangsaan Malaysia. Food Control 2014, 37, 210-217.

20. Rosnani, A.H.; Son, R.; Mohhidin, O.; Toh, P.S.; Chai, L.C. Assessment of knowledge, attitude and practices concerning food safety among restaurant workers in Putrajaya, Malaysia. Food Sci. Qual. Manag. 2014, 32, 20-27.

21. Ministry of Health (MOH). Health Facts 2013; MOH: Putrajaya, Malaysia, 2013. Available online: http://vlib.moh. gov.my/cms/content.jsp?id=com.tms.cms.section.Section_3549ea8f-c0a81049-874bd300-302e756b (accessed on 3 May 2015).

22. Osaili, T.M.; Jamous, D.O.A.; Obeidat, B.A.; Bawadi, H.A.; Tayyem, R.F. Food safety knowledge among food workers in restaurants in Jordan. Food Control 2013, 31, 145-150. [CrossRef]

23. Pichler, J.; Ziegler, J.; Aldrian, U.; Allerberger, F. Evaluating levels of knowledge on food safety among food handlers from restaurants and various catering businesses in Vienna, Austria 2011/2012. Food Control 2014, 35, 33-40. [CrossRef]

24. Lee, J.Y.; Choi, J.W.; Kim, H. Determination of hand surface area by sex and body shape using alginate. J. Physiol. Anthropol. 2007, 26, 475-483. [CrossRef] [PubMed] 
25. Tan, S.L.; Lee, H.Y.; Abu Bakar, F.; Abdul Karim, M.S.; Rukayadi, Y.; Mahyudin, N.A. Microbiological quality on food handlers' hands at primary schools in Hulu Langat district, Malaysia. Int. Food Res. J. 2013, 20, 2973-2977.

26. Sneed, J.; Strohbehn, C.; Gilmore, S.A.; Mendonca, A. Microbiological evaluation of foodservice contact surfaces in Iowa assisted-living facilities. J. Am. Diet. Assoc. 2004, 104, 1722-1724. [CrossRef] [PubMed]

27. Alvarez, J.; Sota, M.; Vivanco, A.; Perales, I.; Cisterna, R.; Rementeria, A.; Garaizar, J. Development of a multiplex PCR technique for detection and epidemiological typing of Salmonella in human clinical samples. J. Clin. Microbiol. 2004, 42, 1734-1738. [CrossRef]

28. Teh, C.S.J.; Chua, K.H.; Thong, K.L. Simultaneous differential detection of human pathogenic and non-pathogenic Vibrio species using a multiplex PCR based on gyrB and pntA genes. J. Appl. Microbiol. 2010, 108, 1940-1945. [PubMed]

29. Saad, M.; Toh, P.S.; Adil, M.A.M. Hygiene practices of food handlers at Malaysian government institutions training centers. Procedia Soc. Behav. Sci. 2013, 85, 118-127. [CrossRef]

30. Liu, S.; Liu, Z.; Zhang, H.; Lu, L.; Liang, J.; Huang, Q. Knowledge, attitude and practices of food safety amongst food handlers in the coastal resort of Guangdong, China. Food Control 2015, 47, 457-461. [CrossRef]

31. McIntyre, L.; Vallaster, L.; Wilcott, L.; Henderson, S.; Kosatsky, T. Evaluation of food safety knowledge, attitudes and self-reported hand washing practices in foodsafe trained and untrained food handlers in British Columbia, Canada. Food Control 2013, 30, 150-156. [CrossRef]

32. Lynch, R.A.; Elledge, B.L.; Griffith, C.C.; Boatright, D.T. A comparison of food safety knowledge among restaurant managers, by source of training and experience, in Oklahoma County, Oklahoma. J. Environ. Health 2003, 66, 9-14. [PubMed]

33. Toh, P.S.; Birchenough, A. Food safety knowledge and attitudes: Culture and environment impact on hawkers in Malaysia. Knowledge and attitudes are key attributes of concern in hawker food handling practices and outbreaks of food poisoning and their prevention. Food Control 2000, 11, 447-452. [CrossRef]

34. Todd, E.C.; Greig, J.D.; Batleson, C.A.; Michaels, B.S. Outbreaks where food workers have been implicated in the spread of foodborne disease. Part 3. Factors contributing to outbreaks and description of outbreak categories. J. Food Prot. 2007, 70, 2199-2217. [CrossRef] [PubMed]

35. Ackerley, L. Consumer awareness of food hygiene and food poisoning. Environ. Health 1994, 102, 69-74.

36. Curtis, V.; Cousens, S.; Mentens, T.; Kenki, B.; Diallo, I. Structured observations of hygiene behaviours in Burkira Faso: Validity, variability and utility. Bull. World Health Organ. 1993, 71, 23-32. [PubMed]

37. Pinfold, J.V. Analysis of different communication channels for promoting hygiene behavior. Health Educ. Res. 1999, 14, 629-639. [CrossRef] [PubMed]

38. Worsfold, D.; Griffth, C.; Worsfold, P. A survey of environmental health officers' views of food hygiene training. Br. Food J. 2004, 106, 51-64. [CrossRef]

39. Seaman, P.; Eves, A. Perceptions of hygiene training amongst food handlers, managers and training providers-A qualitative study. Food Control 2010, 21, 1037-1041. [CrossRef] 